\title{
Primary Squamous Cell Carcinoma of the Stomach: A Case Report
}

\author{
Onder TONYALI ${ }^{1}$, Mustafa BENEKLI ${ }^{1}$, Tarkan KARAKAN ${ }^{2}$, Mustafa KEREM ${ }^{3}$, Ayse DURSUN ${ }^{4}$, \\ Ugur COSKUN $^{1}$, Suleyman BUYUKBERBER ${ }^{1}$ \\ ${ }^{1}$ Gazi University Faculty of Medicine, Department of Medical Oncology \\ ${ }^{2}$ Gazi University Faculty of Medicine, Department of Gastroenterology \\ ${ }^{3}$ Gazi University Faculty of Medicine, Department of General Surgery \\ ${ }^{4}$ Gazi University Faculty of Medicine, Department of Pathology, Ankara, TURKEY
}

To the editor,

A 59-year-old man presented with a 6-month history of dyspepsia and $20 \mathrm{~kg}$ weight loss. His past medical history was unremarkable. His father had died of gastric cancer 10 years ago. He was a non-smoker with no history of alcohol abuse. Because of these complaints, he underwent three esophagoduodenoscopy (EGD) procedures in previous three months. These EGDs showed linitis plastica characterized by erythematous and edematous thickened gastric folds and spaced nodularity with erosions in the whole stomach. Biopsies were all negative. His physical examination revealed epigastric sensitivity. On laboratory examination, complete blood count, kidney and liver function tests were normal. An abdominal computed tomography (CT) demonstrated diffuse thickening of gastric fundus and corpus wall as well as peritoneal implants, perigastric lymphadenopathies and ascites in the right paracolic area and Douglas' pouch. Thorax CT was normal. Serum CA 19-9 level was elevated as $855.07 \mathrm{U} / \mathrm{ml}(\mathrm{n}<37)$. An endoscopic ultrasonography (EUS) showed wide-spread tumoral infiltration in the submucosal layer of gastric wall. A biopsy was unremarkable. After repetitive failure of non-invasive diagnostic procedures, a diagnostic laparoscopy was performed. Peritoneal implants were seen between left liver lobe and anterior abdominal wall, on the anterior surface of the stomach and omentum. Biopsy of peritoneal implants showed solid tumoral islands composed of atypical cells characterized with large vesicular nuclei with prominent nucleoli and abundant eosinophilic cytoplasm. Immunohistochemical examination of the tumor cells revealed diffuse staining for cytocheratin (CK) 5/6 and p63. CK7 was negative. Morphologic and immunohistochemical features were found to be consistent with the diagnosis of squamous cell carcinoma (SCC) (Figure 1). After a brief workup in search of an extragastic primary, stage 4 primary squamous cell carcinoma of stomach was diagnosed. Palliative chemotherapy, including cisplatin $\left(60 \mathrm{mg} / \mathrm{m}^{2}\right.$ bolus infusion, day 1$)$, docetaxel $\left(60 \mathrm{mg} / \mathrm{m}^{2}\right.$ bolus infusion, day 1), leucovorin ( $400 \mathrm{mg} / \mathrm{m}^{2}$ bolus infusion, day 1) and 5-fluorouracil $\left(2400 \mathrm{mg} / \mathrm{m}^{2} / 46\right.$ hours infusion, day 1) was started. After 2 cycles of chemotherapy, stable disease was achieved. Treatment was discontinued after 4 cycles because of lack of response, side effects and worsening performance status. Four months after the diagnosis, the patient died due to disease progression.

Primary squamous cell carcinoma of the stomach (PSCCS) is extremely rare with less than 100 cases of PSCCS reported in the English literature and accounts for nearly $0.04-0.07 \%$ of all gastric carcinomas. ${ }^{1}$ It was first reported by Rörig in $1895 .^{2}$ The diagnostic criteria for PSCCS are as follows: (1) the tumor must not be located in the cardia; (2) the tumor must not extend into the esophagus; and (3) there must be no evidence of squamous cell carcinoma in any other organ. ${ }^{3}$ Our case was compatible with the diagnostic criteria of PSCCS. Although biopsy of the peritoneal implants yielded the diagnosis of the disease, EUS proved the primary gastric origin. As in our patient, routine diagnostic procedures including EUS may be inadequate in the PSCCS and diagnostic laparotomy is frequently required. ${ }^{4}$ 


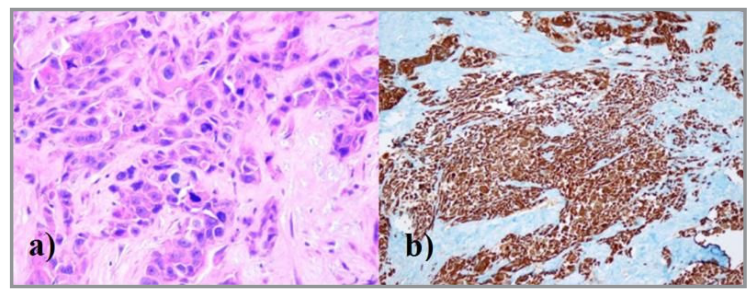

Figure 1. Biopsy of the peritoneal implants. a) Squamous cell carcinoma infiltration ( $40 \times$ magnifications) b) Diffuse staining of tumor cells with cytokeratin 5-6 (10 x magnifications).

Histologically, poorly differentiated carcinoma of the stomach may be confused with PSCCS. Therefore, Boswell and Helwig ${ }^{5}$ identified four histological criteria of which at least one is necessary for diagnosis of PSCCS: (1) Keratinizing cell with pearl formation; (2) mosaic pattern of cell arrangement with sharp cell borders; (3) presence of intercellular bridges; and (4) demonstration of sulfhydryl and/or disulfide groups indicating the presence of keratin or prekeratin. Histopathologic examination of the present case met these criteria (Figure 1).

The pathogenesis of PSCCS is still unknown. Squamous metaplasia of the gastric mucosa before malignant transformation seems to be the most logical theory. Other theories including squamous differentiation from nests of ectopic squamous cells in gastric mucosa, preexisting adenocarcinoma, totipotential stem cells in the gastric mucosa and gastric vascular endothelial cells have not been proved. ${ }^{1}$ Gastric squamous metaplasia may develop due to extrinsic and intrinsic damage, such as corrosive gastric acid burns, luetic linitis plastica, in foci of chronic inflammation in Menetrier disease, after chemotherapy for well-differentiated lymphocytic lymphoma and long period cyclophosphamide therapy. ${ }^{6}$ Our patient did not have any known risk factor for developing of PSCCS.

PSCCS has poor clinical prognosis. Distant metastases to liver, lymph nodes and other organs occur aggressively in the early period. ${ }^{7}$ In 1960 s, PSCCS was suggested to have more favorable prognosis than adenocarcinoma of the stomach. ${ }^{2}$ However, more recent reports suggested the opposite. ${ }^{8}$ Overall survival rates vary from a few months to a few years. ${ }^{6}$ The present case had poor prognosis with 4 months of overall survival.

The only potential curative treatment approach is surgery in localized disease. ${ }^{1,3,5}$ Addition of adjuvant polychemotherapy to radical surgical intervention provides the best overall survival., ${ }^{2,9}$ There is no standard chemotherapy in advanced and metastatic disease. Yanasiwaga at al. ${ }^{10}$ reported that pathological complete response was achieved after 3 cycles of
DCF (docetaxel $75 \mathrm{mg} / \mathrm{m}^{2}$ day 1 , cisplatin $75 \mathrm{mg} / \mathrm{m}^{2}$ day 1 and 5 fluorouracil $750 \mathrm{mg} / \mathrm{m}^{2} 1-5$ day) combination chemotherapy. We administered 4 cycles of modified DCF combination chemotherapy with a brief period of disease stabilization.

Our knowledge about the PSCCS is limited to reported cases in the literature. Although diagnostic criteria were established for PSCCS, we do not have any consensus for its treatment. Palliative chemotherapy should be considered in selected cases in advanced disease. We need large case series for more precise information.

\section{REFERENCES}

1. Straus R, Henschel S, Fortman DJ. Primary adenosquamous carcinoma of the stomach: a case report and review. Cancer 24: 985-995, 1969.

2. Altshuler JH, Shaka JA. Squamous cell carcinoma of the stomach. Review of the literature and report of a case. Cancer 19: 831-838, 1966.

3. Parks RE. Squamous neoplasms of the stomach. Am J Roentgenol Radium Ther Nucl Med 101: 447-449, 1967.

4. Schwab G, Wetscher G, Dietze O, et al. Primary squamous cell carcinoma of the stomach in a seventeen-year-old boy. Surg Today 22: 561-564, 1992.

5. Boswell JT, Helwig EB. Squamous cell carcinoma and adenoacanthoma of the stomach: A clinicopathologic study. Cancer 18: 181-192, 1965.

6. Chan APH, Wong S, Mak KL, et al. Primary squamous cell carcinoma of the stomach. Surg Pract 10: 79-81, 2006.

7. Mori M, Iwashita A, Enjoji M. Squamous cell carcinoma of the stomach: report of three cases. Am J Gastroenterol 81: 339342, 1986.

8. Volpe CM, Hameer HR, Masetti P, et al. Squamous cell carcinoma of the stomach. Am Surg 61: 1076-1078, 1995.

9. Ruck P, Wehrmann M, Campbell M, et al. Squamous cell carcinoma of the gastric stump: A case report and review of the literature. Am J Surg Pathol 13: 317-324, 1989.

10. Yanagisawa S, Tsuchiya S, Kaiho T, et al. Histological complete response in a case of primary squamous cell carcinoma of the stomach treated by chemotherapy with docetaxel and cisplatin plus 5-fluorouracil. Gan To Kagaku Ryoho 37: $307-$ 310, 2010.

\section{Correspondence}

Dr. Önder TONYALI

Gazi Üniversitesi Tıp Fakültesi

Tıbbi Onkoloji Bilim Dalı

ANKARA / TURKEY

Tel: (+90.312) 2025825

Fax: (+90.312) 2158710

e-mail: tonyalionder@yahoo.com 